\title{
La escuela del diablo: la superstición en la demonología de Jacobo VI*
}

The devil's school: superstition in James Vl's demonology

\section{- María Victoria Lallana}

Universidad de Buenos Aires

Fecha de Recepción: Noviembre 2018. Fecha de Aceptación: Noviembre 2018.

\section{Resumen}

El presente trabajo se propone analizar la relevancia del concepto de superstición en la Demonología (1597) de Jacobo VI de Escocia, en particular enfocándose en el Libro III del tratado. Se intentará mostrar que la utilización del este modelo analítico colabora a interpretar la forma en que se conciben los espíritus y entidades folclóricas estudiadas en la tercera parte. Se pondrá especial énfasis en la noción de pacto tácito, dispositivo que funciona como denominador común entre los diversos libros que componen la Demonología. Asimismo, esta interpretación permite vincular a la obra con el acta contra brujería de 1563, y las concepciones calvinistas más amplias en términos de supersticiones.

\begin{abstract}
This article analyzes the relevance of the concept of superstition with respect to James VI of Scotland's Daemonologie (1597), with a particular focus on Book III of the treatise. It aims to show how the use of this particular analytical model helps to understand the way spirits and folk entities are conceived. The notion of the tacit pact will be emphasized as a common denominator between the different books that compose the Daemonologie. Additionally, this interpretation allows us to link James's work with the 1563 Witchcraft Act and the broader Calvinist conceptions regarding superstitions.
\end{abstract}

Si bien los orígenes del concepto de superstición se remontan a la antigua Grecia, fue Agustín de Hipona, en el ámbito cristiano, el primero en unificar bajo un término único

* Artículo entregado en el marco de las VII Jornadas de Reflexión Histórica: Las formas del conflicto religioso y de la violencia simbólica en el espacio cultural europeo (siglos XIV a XVIII): actores, dispositivos, escenarios, estrategias", organizadas por el Instituto de Historia Antigua y Medieval, (Facultad de Filosofía y Letras, Universidad de Buenos Aires), el 5 de diciembre de 2018

Palabras clave

Demonología

Escocia

Hadas

Jacobo VI

Superstición

Keywords

Demonology

Faeries

James VI

Scotland

Superstition 
prácticas de orden cultual con otros excesos y prácticas no cultuales. Esta operación - que no carecía de arbitrariedad- las agrupaba bajo un denominador común: eran vanas por ser incapaces de producir el efecto esperado de ellas. Se incluían aquí la adivinación, la utilización de remedios no sancionados por la medicina de la época, las vanas observancias. Al producirse un resultado esperado, pero que por virtudes de las propiedades naturales de los objetos involucrados era imposible, entonces -sostiene Agustín- no se trata de eficacia sino de la intervención del diablo. Varios siglos más tarde será Tomás de Aquino quien, buscando superar algunas de las inconsistencias del modelo agustiniano de supersticiones, profundice la vinculación entre la acción del demonio y la producción de efectos reales a partir de prácticas vanas. Su mayor aporte a la consolidación del modelo es la noción de pacto tácito, a partir de la cual se produce la demonización absoluta de estas creencias y prácticas de manera independiente de las intenciones de sus practicantes. Para comprender su gravedad, es necesario tener en cuenta el importante cambio operado en el sistema moral medieval representado por los siete pecados capitales, a uno en dónde el eje estaba puesto en los Diez Mandamientos. Con el Decálogo como foco, los pecados en contra del primer mandamiento -es decir, la idolatría- adquirían una relevancia fundamental (Campagne, 2002: 53-115; Clark, 1997: 32; 1991; Levack, 2006: 1 y 2).

Con este contexto en mente es que hay que interpretar la utilización de la palabra superstición en la pieza legal más importante para la represión religiosa en Escocia entre los siglos XVI y XVIII: el acta contra brujería de 1563. Su nombre parece indicar que se trata de una legislación destinada a perseguir el crimen colectivo de la brujería bajo la forma que adquirió en la temprana modernidad. ${ }^{1}$ Entre otras cosas, no hay menciones a pactos con el diablo, ni a reuniones nocturnas. El foco del acta radica en la supresión de prácticas y creencias supersticiosas, ${ }^{2}$ vinculadas a las vanas observancias y los remedios populares. Más allá de las intenciones inmediatas del autor -que, como argumenta Julian Goodare sea posiblemente el gran artífice de la Reforma escocesa, John Knox- esta ley fue una de las piezas claves para habilitar la caza de brujas en Escocia. ${ }^{3}$ Fue, asimismo, el comienzo de la demonización de la cultura popular (Cowan, 2008) y un antecedente importante al tratado de demonología escrito por Jacobo VI.

El objetivo de este trabajo es analizar la Daemonologie a la luz del discurso anti-supersticioso. La misma está escrita en forma de diálogo en el cual el erudito Epistemón instruye a Philomates sobre la realidad de las prácticas mágicas. Está compuesta de tres libros, de los cuáles sólo el II está dedicado a la brujería.

\section{Demonios folclóricos}

Al comenzar su exposición del libro III, el rey emite una advertencia: ${ }^{4}$ con el fin de pertubar, engañar y conducir al error, los demonios pueden adoptar diversas formas y nombres. Esta fachada se aplica en especial a los considerados "buenos espíritus", ya que a los fines teológicos no importa si sus acciones resultan beneficiosas. Jacobo es taxativo al respecto. Las escrituras determinan que la era de visiones y profecías está concluida. ${ }^{5}$ El tópico del fin de los milagros está lejos de ser una particularidad de la Daemonologie sino que es recurrente en la teología protestante. ${ }^{6}$

Los espíritus que atormentan a las casas o los lugares solitarios son referidos por Jacobo como lemures o spectra, de aspecto horroroso y atemorizante. ${ }^{7}$ En el caso de aparecer bajo la guisa de un difunto conocido se los menciona como umbrae mortuorum, o wraith al tratarse de una premonición de muerte o de una persona recientemente fallecida. ${ }^{8}$ La existencia de fantasmas -entendida como la aparición del alma de los muertos- fue un tema extensamente discutido por los teólogos reformados. El
1. Utilizamos la definición de concepto acumulativo de la brujería como está definido en Levack (2006: cap. 2). 2. Dice el acta: "Estatis in this present Parliament being informit, that the havy and abominabill superstitioun usit be divers of the liegis of this Realme, be using of Witchcraftis, Sorsarie and Necromancie, and credence gevin thairto in tymes bygane aganis the Law of God: And for avoyding and away putting of all sic vane superstitioun in tymes tocum", la cita se obtuvo en Goodare (2005a). 3. "The Witchcraft Act". Para un desarrollo detallado sobre el origen y el significado del Acta ver Goodare (2005b), Larner (1984a: 6-68), Normand y Roberts (2000: 89-92). 4. "Now it restes to speake of their naturall comming as it were, and not raysed by Witch-craft. [...] that although in my discourseing of them, I deuyde them in diuers kindes, yee must notwithstanding there of note my Phrase of speaking in that: For doubtleslie they are in effect, but all one kinde of spirites, who for abusing the more of mankinde, takes on these sundrie shapes, and vses diuerse formes of out-ward actiones, as if some were of nature better then other" (Jacobo VI, 1597: 57).

5. "(...) all we that are Christians, ought assuredly to know that since the comming of Christ in the flesh, and establishing of his Church by the Apostles, all miracles, visions, prophecies, $\varepsilon$ appearances of Angels or good spirites are ceased. Which serued onely for the first sowing offaith, \& planting of the Church", Daemonologie, pp. 65-66.

6. En efecto suscriben a él figuras que se encuentran en las antípodas respecto a la creencia en brujería, como el inglés Reginald Scot, cuyos argumentos Jacobo pretende rebatir en este tratado (Scot, 1584: 181). Ver también Clark (1997: 263), Cameron (2010: 206-208).

7. Daemonologie, pp. 57

8. Daemonologie, pp. 61 
rechazo del purgatorio como una construcción escolástica carente de sustento bíblico los condujo a concluir casi unánimemente en su imposibilidad (Cameron, 2010: 187-191). ${ }^{9}$ Jacobo se apoya en las Escrituras para sostener esta idea argumentando que después de la destrucción de Babel y Edom, estos lugares desolados, fueron habitados por espíritus dañinos. ${ }^{10}$

En contraposición, estaban los personajes folclóricos benéficos. El brownie ${ }^{11}$ usualmente se representaba como un hombrecillo de color oscuro (Miller, 2008: 151-152). Se trataba de un espíritu doméstico, asociado a un núcleo familiar y que realizaba una cantidad sobrehumana de labores del hogar. Se considera que su presencia atrae a la buena suerte. ${ }^{12}$

De todas las criaturas o espíritus mencionados, son las hadas ${ }^{13}$ las que merecen nuestra mayor atención. Esbozar una definición de las hadas presenta algunos problemas, ya que el término es genérico y engloba un amplio espectro de seres sobrenaturales. ${ }^{14}$ En el nivel popular, su utilización parece ser intercambiable con la de ángeles; en el de la alta cultural teologal con la de demonios. La asociación más frecuente es con los muertos, en particular con las almas de familiares y amigos que habían fallecido -aquellos que Jacobo identifica como umbrae mortuorom- (Wilby, 2005: 17-19). ${ }^{15}$ Por otro lado, hasta finales de siglo XVII, con la publicación de The Secret Common-Wealth of Elves, Fauns and Fairies por Robert Kirk, no existió ninguna compilación exhaustiva de las mismas. La mayoría de las referencias provienen de la literatura erudita o de los registros judiciales de la cacería de brujas, en particular de la escocesa. Para Emma Wilby la cantidad de confesiones que las involucran son una muestra de la extensión de la creencia en hadas. En dichos registros se puede apreciar el esfuerzo por parte de los interrogadores para reconfigurar los testimonios para encajar con el estereotipo demonológico (Wilby, 2005: 24).

Las hadas, si bien ontológicamente distinguibles, tenían comportamientos muy semejantes a los de los seres humanos.

How there was a King and Queene of Phairie, of such a iolly court \& train as they had, how they had a teynd, \& dutie, as it were, of all goods: how they naturallie rode and went, eate and drank, and did all other actiones like naturall men and women $^{16}$

Estas acciones mencionadas por Jacobo incluían matrimonio y producción de descendencia, labores hogareñas o del campo y cazar, entre otras. Vivían en comunidades o en solitario, tanto en lugares aislados como cerca de los humanos. Eran, además y principalmente, criaturas con poderes sobrenaturales. Entre sus habilidades debemos contar la adivinación, el vuelo, la curación, el conocimiento de cosas por venir o ubicaciones de objetos perdidos. Su capacidad de influenciar las vidas de las personas era considerada, por esta razón, muy grande. En general se aceptaba que las hadas tenían un rango de conductas muy variable en relación con los hombres, entre la benevolencia y la pura maldad. Para favorecer la buena voluntad de las hadas, existían una miríada de conductas y pequeños rituales que las personas podían realizar, tales como dejar alimentos o pronunciar encantamientos. Estas observancias funcionaban así como precauciones a la vez que súplicas. En reconocimiento, las hadas podían proveer favores mágicos, incluso dotar de poderes a sus receptores (Wilby, 2005: 19-21).

Jacobo sostiene que los espíritus denominados hadas eran aquellos conocidos como Diana y su corte ambulante ${ }^{17}$ por "los gentiles". Esto remite de manera inmediata, aunque no sea una referencia explícita, al Canon Episcopi. Este fragmento de documento representa de manera estereotípica el escepticismo característico de la Edad Media respecto a la posibilidad de los demonios de ejercer efectos reales en la
9. En el comienzo del tratado, Jacobo sienta su posición al respecto al referirse al episodio de la bruja de Endor, en el cual a pedido de Saúl el alma el profeta Samuel es supuestamente conjurada. En verdad se trata de un engaño debido a la capacidad de los demonios de adoptar variadas formas y apariencias. Daemonologie, Libro I, cap. I; Normand y Roberts argumentan que la peculiar lectura de esta historia puede estar influenciada por Scot (Normand y Roberts, 2000: 335-336). 10. Las citas mencionadas en el tratado corresponden a Isaías, 13 y 34 y Jeremías 50, Daemonologie, pp. 59. Normand y Roberts señalan que estos versículos solían ser utilizados como fuente de autoridad en relación a las discusiones pneumatológicas (Normand y Roberts, 2000: 405).

11. Goodare sostiene que parece haber una diferenciación brownies y hadas en la creencia popular, aunque ambos entran dentro la categoría más amplia de espíritus de la naturaleza (Goodare, 2013: 150). Algunos folcloristas e historiadores utilizan el término hadas en un sentido más general y ubican a estas criaturas dentro de los mismos (Wilby, 2000: 284).

12. Daemonologie, p. 65 .

13. Por cuestiones de convención semántica se mantendrá el uso del femenino en referencia a estas criaturas, pero debe ser notado que el original en scots -también en inglés-carece de género gramatical y el término "fairies" o "phairies" incluye tanto a representaciones femeninas como masculinas. 14. Para estas definiciones, ver Wilby (2000: 284-285), Wilby (2005: 17-25), Egger (2014: 32-58). 15. Goodare contrargumenta que la creencia en fantasmas, ángeles, demonios (entre otros) se mantenía separada en la cultura popular (Goodare, 2013). 16. Daemonologie, pp. 74.

17. Asimismo, remite a la figura de la "cacería salvaje" o la "horda furiosa”, una procesión de fantasmas de difuntos prematuros condenada a vagar por la tierra. Goodare sostiene que la creencia existía en Escocia, ya que si bien no hay fuentes que la registren por completo, muchos de sus elementos constitutivos pueden encontrarse en confesiones de brujas (Goodare, 2008: 32-33). 
materia. Su alcance -y su función, de acuerdo con la tesis de ministerialidad- consiste en implantar ilusiones en la mente de las personas (Campagne, 2002: 64). Jacobo se refiere a estos hechos del mismo modo: las personas que creen visitar el país de las hadas están bajo el influjo engañoso del diablo, en realidad no se han movido de sus camas. ${ }^{18}$ Jacobo pone en boca de Philomates una pregunta clave: ¿si sólo se trata de una ilusión, por qué muchas brujas fueron ejecutadas por confesar asistir a estas reuniones? ${ }^{19}$ Como respuesta Epistemón sostiene que este tipo de ataques demoníacos pueden ocurrir, en principio, a cualquier individuo con la finalidad de atemorizarlas. Son aquellas se entregan voluntariamente a la ilusión, que cooperan y reciben de las hadas objetos mágicos o profecías quienes deben ser castigadas. Estas personas son, a su vez, designadas como brujas. ¿Significa esto que en realidad los únicos sujetos pasibles de ser cooptados por el demonio son aquellos que ya previamente lo aceptaron como maestro? Una afirmación realizada por Epistemón luego de repasar diversos nombres con los cuales el diablo se presenta ante magos y nigromantes puede colaborar a iluminar este interrogante:

Euen so I say he deceaues the Witches, by attributing to himselfe diuers names: as if euery diuers shape that he trans formes himselfe in, were a diuers kinde of spirit

Si seguimos el razonamiento del engaño, estas "brujas" son manipuladas para creer que están tratando con seres de otra naturaleza - aunque, como ya se ha visto, no necesariamente benignas. Se puede argumentar entonces que lo que se está castigando, en un caso como este, es el pacto tácito que habilitaría la utilización de los implementos mágicos antes mencionados. ${ }^{20}$ Otra posibilidad sería que las personas capaces de aceptar la realidad de las reuniones con hadas son aquellas que ya son brujas consumadas. En este caso lo que las condenaría sería la idolatría expresa. En todos los casos, les correspondía un castigo igual o más severo que a cualquier otra bruja. ${ }^{21}$ Es decir, la muerte.

Sin embargo, los testimonios parecen apoyar la idea que algunas mujeres condenadas como brujas creían estar tratando con entidades diferentes a demonios. Agnes Sampson, una de las brujas de North Berwick - proceso que motivó la escritura del tratado que se estudia en este trabajo- confesó en 1591 haber hecho un pacto con un espíritu no identificado (Goodare, 2013: 157). Esto la coloca en una posición más parecida a la que el propio Jacobo describe para los magos y nigromantes que para las brujas. ${ }^{22}$ Un caso paradigmático y extensamente estudiado es el de Bessie Dunlop (1576) en el cual había recibido el poder de curar de parte del fantasma de Thomas Reid, un vecino fallecido en la batalla de Pinkie (Henderson, 2009; Wilby, 2005: prefacio e introducción; 2000; Macdonald, 2002: 35).

\section{A modo de conclusión}

La demonización de las creencias campesinas fue un proceso extendido a lo largo del tiempo. Podemos fechar su inicio en la Reforma, en particular a partir de la promulgación del acta contra brujería. El libro III de la Demonología de Jacobo suele quedar relegado en los análisis dedicados a la caza de brujas. Sin embargo, al examinarlo bajo la óptica de la extirpación de supersticiones podemos apreciar pertenece a la misma matriz de pensamiento que inspiró la redacción del acta. En algún sentido, ambos esfuerzos están destinados a difundir las ideas reformadas, las creencias correctas.

La progresiva asimilación del mundo feérico con la brujería ya estaba ocurriendo en la realidad, y en la Demonología encuentra su primera formulación teórica. Las ansiedades temprano modernas en relación a la acción del diablo en el mundo encontraron en los practicantes de magia los blancos más claros, pero también impactaron
18. "I say that, euen as I said before of that imaginar rauishing of the spirite foorth of the bodie. For may not the deuil object to their fantasie, their senses being dulled, and as it were a sleepe, such hilles $\&$ houses within them, such glistering courts and traines, and whatsoeuer such like wherewith he pleaseth to delude them", Daemonologie, pp. 75-76. 19. "But how can it be then, that sundrie Witches haue gone to death with that confession, that they haue ben transported with the Phairie to such a hill, which opening, they went in, and there saw a faire Queene, who being now lighter, gaue them a stone that had sundrie vertues, which at sundrie times hath bene produced in judgement?", Daemonologie, pp. 75.

20. Daemonologie, pp. $75-$ 76. Ver supra n. 25 .

21. "That sorte I say, ought as seuerely to be punished as any other Witches, and rather the more, that that they goe dissemblingly to woorke", Daemonologie, pp. 75-76. 22. "Where, finding at the first, that such diuers formes of circles $\&$ conjurations rightlie joyned thereunto, will raise such divers formes of spirites, to resolue them of their doubts: and attributing the doing thereof, to the power inseparablie tyed, or inherent in the circles: and manie words of God, confusedlie wrapped in; (...) Where, in the meane time (miserable wretches) they are become in verie deede, bond-slaues to their mortall enemie: and their knowledge, for all that they presume thereof, is nothing increased, except in knowing evill, and the horrors of Hell for punishment thereof, as Adams was by the eating of the forbidden tree", Daemonologie, pp. 10-11 
sobre las creencias populares (Henderson, 2011: 6). El tratamiento de las hadas en este tratado refleja, aunque de manera incompleta, que la construcción de los estereotipos asociados a la brujería son el resultado de una tensión entre creencias populares y la alta cultural teologal (Larner, 1984b: 136; Ginzburg, 1991: Introducción y cap. 1).

Durante mucho tiempo hubo consenso historiográfico respecto a que la introducción de la noción de pacto con el diablo y del estereotipo del sabbat fueron producto del tratado de Jacobo (Larner, 1984c; Clark, 1977: 157). Hoy sabemos que en las décadas que separan a ambos documentos, hubo caza de brujas aunque su intensidad haya sido mucho menor que en período posterior a 1590, luego de la intervención del monarca (Levack, 2008, 39; Macdonald, 2010: 9; Wasser, 2013).

El pacto es la noción que figura como denominador común a los tres libros que componen la Daemonologie y el rey describe diversos escenarios en los cuáles ese pacto puede ser tácito. Es el concepto de superstición el que le da coherencia al planteo y permite entender por qué Jacobo VI considera que son transgresiones lo suficientemente graves como para ser pagadas con la propia vida. 


\section{Bibliografía}

\section{Fuentes primarias}

» Jacobo VI. (1597). Daemonologie, In Forme of a Dialogie Diuided into three Bookes.

» R. Scot (1584). The Discoverie of Witchcraft.

\section{Bibliografía secundaria}

" Cameron, E. (2010). Enchanted Europe: Superstition, Reason, and Religion, 12501750. Oxford: Oxford University Press.

" Campagne, F. (2002). Homo Catholicus. Homo Superstitiosus: el discurso antisupersticioso en la España de los siglos XV a XVIII. Madrid: Miño y Dávila.

" Clark, S. (1997). Thinking with Demons: The Idea of Witchcraft in Early Modern Europe. Oxford: Clarendon Press.

»Clark, S. (1991). "The Rational Witchfinder: Conscience, Demonologial Naturalism and Popular Superstitions", en Pumfrey S., Rossi P. y Slawinski M. (eds) Science, Culture and Popular Belief in Renaissance Europe. Manchester: Manchester University Press.

»Clark, S. (1977). “King James’s Daemonology: Witchcraft and Kingship”, en Anglo S. (ed.), The damned art. Essays in the literature of witchcraft. London: Routledge \& Kegan Paul.

»Cowan, E. (2008). "Witch Persecution and Folk Belief in Lowland Scotland", en J. Goodare et al. (ed), Witchcraft and belief in Early Modern Scotland. Palgrave McMillan.

"Egger, R. (2014). "Fairies, Witches, and the Devil: The Interface Between Elite Demonology and Folk Belief in Early Modern Scottish Witchcraft Trials" (tesis de maestría), Universidad de Viena.

»Goodare, J. (2013). "Boundaries to the Fairy Realm in Scotland", Olsen K. y J. Veenstra (eds.) Airy Nothings: Imagining the Otherworld of Faerie from the Middle Ages to the Age of Reason. Brill: Leiden.

"Goodare, J. (2008). "Scottish Witchcraft in its European Context", J. Goodare, et al. (ed), Witchcraft and belief in Early Modern Scotland. Palgrave McMillan.

" Goodare, J. (2005a). “The Scottish Witchcraft Act”, Church History 74.1.

» Goodare, J. (2005b). “John Knox on Demonology and Witchcraft," en Archiv fur Reformationsgeschichte, 96.

» Henderson, L. (2009). "Witch, Fairy and Folktale Narratives in the Trial of Bessie Dunlop", Henderson L., (ed) Fantastical Imaginations: The Supernatural in Scottish History and Culture. John Donald, Edinburgh.

» Larner, C. (1984a). Witchcraft and Religion: The Politics of Popular Belief. Oxford: Blackwell.

»Larner, C. (1984b [1981]). Enemies of God. Oxford: Blackwell. 
»Larner, C. (1984C). “King James VI and Witch-craft” en A. Macfarlane (ed.), Witchcraft and Religion: The Politics of Popular Belief. Oxford: Blackwell.

»Levack, B. (2008). Witch-hunting in Scotland: Law, Politics and Religion. Abingdon: Routledge.

»Levack, B. (2006 [1984]). The Witch Hunt in Early Modern Europe. Harlow: Pearson/Longman.

"Normand, L. y Roberts, G. (eds.) (2000). Witchcraft in Early Modern Scotland. James Vl's Demonology and the North Berwick Witches. Exeter: University of Exeter.

» Macdonald, S. (2010). "Creating a Godly Society: Witch-hunts, Discipline and Reformation in Scotland" en Historical Papers, Canadian Society of Church History.

» Macdonald, S. (2002). "In search of the Devil in Fife witchcraft cases, 15601705", Goodare (ed) The Scottish witch-hunt in context. Manchester: Manchester University Press.

»Miller, J. (2008). "Men in Black: Appearances of the Devil in Early Modern Scottish Witchcraft Discourse", en Goodare, et al. (ed), Witchcraft and belief in Early Modern Scotland. Palgrave, McMillan.

»Wasser, M. (2013). "Scotland's First Witch-Hunt" en Goodare (ed.), Scottish Witches and Witch-Hunters. Palgrave McMillan, Basingstoke.

»Wilby, E. (2005). Cunning Folk and Familiar Spirits: Shamanistic Visionary Traditions in Early Modern British Witchcraft and Magic. Brighton: Sussex Academic Press.

»Wilby, E. (2000). “The Witch's Familiar and the Fairy in Early Modern England and Scotland" Folklore 111.2. 